\title{
On Farm Pre Harvest Agronomic Management Practices of Aspergillus Infection on Groundnut in Abergelle, Tigray
}

Gebreselassie $\mathbf{R}^{1 *}$, Dereje $\mathbf{A}^{2}$ and Solomon $\mathbf{H}^{3}$

${ }^{1}$ Mekelle Agricultural Research Center, crop core process, P.O.Box 258, Mekelle, Ethiopia

${ }^{2}$ Department of Crop and Horticultural Science, Mekelle University, P.O.Box 231, Mekelle, Ethiopia

${ }^{3}$ Department of Land Resource Management and Environmental protection, Mekelle University, P.O.Box 231, Mekelle, Ethiopia

\begin{abstract}
Aspergillus infection and subsequent contamination of groundnut with Aflatoxin is a major limitation in groundnut production in the study area (Tanqua Abergel,Tigray). This study was executed to evaluate the effect of fertilizer (DAP and gypsum application), tied ridging and supplementary irrigation on Aspergillus infection of groundnut. The experiment was laid out in Randomized Complete Block Design with three replications in two sites. DAP as a source of $\mathrm{P}$, and gypsum as source of $\mathrm{Ca}$, were applied at planting and pod setting stages, respectively. While Tied ridging and supplementary irrigation were applied at early flowering and during cessation of rainfall, respectively. Data on incidence and severity levels of Aspergillus infection on sampled kernels were recorded. The analysis of variance indicated that the integrated agronomic management practices showed a significant reduction of Aspergillus flavus infection on groundnut at both experimental sites. The lowest (3\%) Aspergillus flavus infection was recorded in management practices where Supplementary irrigation+tied ridging were practiced at Hadinet. The highest Aspergillus flavus infection (17.3\%) was recorded in the control. In Lemlem experimental site the lowest Aspergillus flavus infection (4.3\%) was recorded in gypsum+supplementary irrigation combination, while highest $(19.3 \%)$ Aspergillus flavus infection was recorded in control. Application of integrated agronomic management practices did not showed a significant reduction of Aspergillus niger infection at both experimental sites.
\end{abstract}

Keywords: Agronomic practices; Aspergillus infection; groundnut

\section{Introduction}

Groundnut is the sixth most important oilseed crop in the world. Groundnut kernels are consumed directly as a raw, roasted or boiled or oil extracted from the kernel is used as culinary oil. The crop is also used as animal feed and industrial raw material. Its multiple use and as a source of income make the crop important besides to its cash crop for domestic markets as well as for foreign trade in several developing and developed countries. Aflatoxin contamination has a significant role in groundnut production. Aflatoxin toxic fungal metabolites mainly produced by Aspergillus flavus and A. parasiticus. Contamination of groundnut with aflatoxin occurs under pre harvest, postharvest handling and storage conditions. The main factors leading to aflatoxin contamination include poor cultural practices; use of damaged and loose shelled kernels as seed and delayed harvesting after physiological maturity aggravates biological and physical effects of aflatoxins [1].

Aspergilli are group of fungi exhibiting immense ecological and metabolic diversity. These include notorious pathogen such as Aspergillus fulvus, which produces aflatoxin, one of the most potent, naturally occurring carcinogenic compounds known to man [1].

The development and contamination of the fungus in poorly managed fields is more serious. Timely planting, adequate fertility, good weeding and insect control, supplementary irrigation, suitable plant population and hybrid selection considerably reduce aflatoxin contamination [2].

The association of mycotoxins with consumption of contaminated groundnut and other food lead many importing countries, including the EU countries, to enact regulations establishing maximum levels for aflatoxins in groundnut and groundnut products [3].

The infection of A.flavus can be minimized to a level where it cannot cause significant damage through the application of different pre- harvest management practices. According to Doner [3] the risk to infection and contamination of aflatoxin can be reduced substantially with proper irrigation supply particularly from flowering to pod setting stages, soil amendments; application of proper and rapid drying after harvest.

Groundnut by now is regarded as a cash crop and is the most important oil crop. The area coverage for groundnut production is constantly increasing. Farmers in Tanqua Abergelle are becoming interested in growing groundnut because of its high price as compared to other cereal and pulse crops. As a result farmers start sharing their land for groundnut production instead of planting the whole land for sorghum and other crop production.

Despite its importance as a food and cash crop in Ethiopia in general and study area in particular the quality of groundnut is poor which is mainly caused by Aspergillus infection at late growth stage of the crop. In addition, little work has been done on the extent of integrated agronomic management practices which improves quality of groundnut. Moreover, late onset and early cessations of rain fall in of Tigray in general and Abergalle in particular are common phenomena. And hence, studying different agronomic management practices that could alleviate such problems and improve quality of groundnut are important to groundnut production [4-6].

*Corresponding author: Mekelle Agricultural Research Center, crop core process, P.O.Box 258, Mekelle Ethiopia, Tel: +251344408030; E-mail: gebrhe62@yahoo.com

Received: March 07, 2014; Accepted May 22, 2014; Published June 01, 2014

Citation: Gebreselassie R, Dereje A, Solomon H (2014) On Farm Pre Harvest Agronomic Management Practices of Aspergillus Infection on Groundnut in Abergelle, Tigray. J Plant Pathol Microb 5: 228. doi:10.4172/2157-7471.1000228

Copyright: @ 2014 Gebreselassie R, et al. This is an open-access article distributed under the terms of the Creative Commons Attribution License, which permits unrestricted use, distribution, and reproduction in any medium, provided the original author and source are credited. 


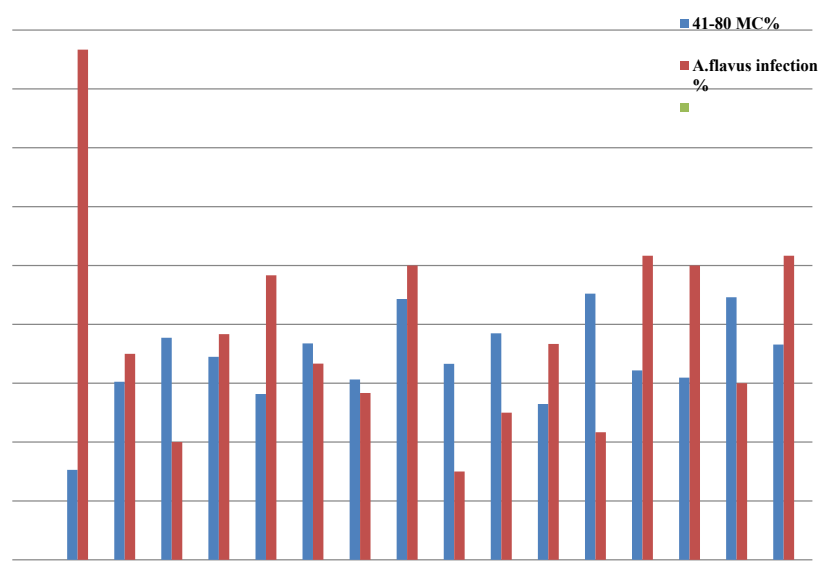

Figure 1: Moisture content retention and Aspergillus infecton in groundnut at $41-80 \mathrm{~cm}$ root depth at Hadinet,Ethiopia.

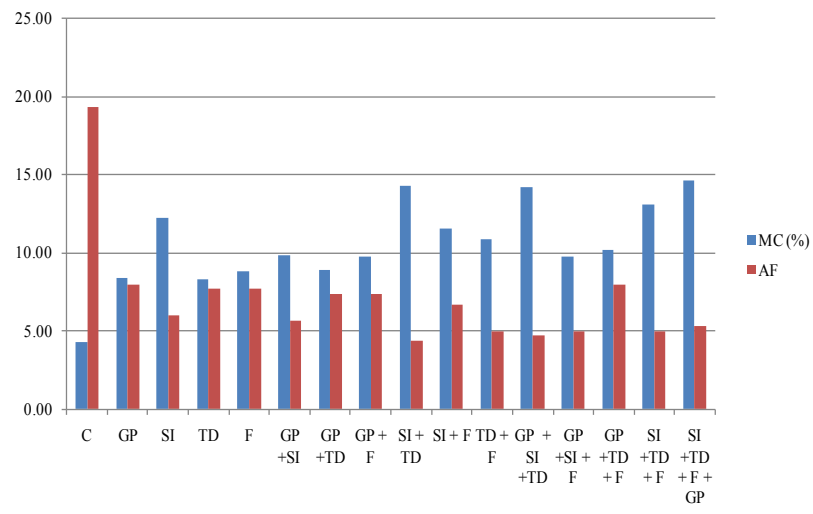

Figure 2: Moisture content retention and Aspergillus infection in groundnut at $41-80 \mathrm{~cm}$ root depth Lemlem.

And hence, the major objective of the study is thus to identify pre harvest agronomic management practices that reduces Aspergillus infection levels.

\section{Materials and Methods}

\section{Description of the study area}

The study was conducted during the 2011 cropping season in Tanqua Abergelle Wereda at Tabia Lemlem and Hadinet in the central administrative Zone of Tigray, northern Ethiopia on sandy soil. Tanqua Abergelle is located $120 \mathrm{kms}$ far from Mekelle at an altitude of 1500 m.a.s.l, $13014^{\prime} 06^{\prime \prime} \mathrm{N}$ Latitude \& $38^{\circ} 58^{\prime} 50^{\prime \prime}$ E longitudes (Figure 1). Agro-ecologically it is characterized as hot warm sub-moist low land (SMl-4b). The mean annual rainfall and temperature range of the wereda is $350-700 \mathrm{~mm} \& 24-41^{\circ} \mathrm{C}$, respectively (Legesse 1999). The mean maximum and minimum temperature of the wereda during the 2011 growing season was $36.4^{\circ} \mathrm{C}$ and $19.5^{\circ} \mathrm{C}$, respectively. While the total rainfall of Hadinet and Lemlem experimental sites during the 2011 growing season were $277 \mathrm{~mm}$ and $314 \mathrm{~mm}$ respectively (Figure 2).

\section{Treatments and experimental design}

As planting material Sedi was used in the study area during the execution of the experiment. The experimental plot was arranged in
RCBD with three replications. Different farmers field were considered as a replication. The total plot size used was $9 \mathrm{~m}^{2}(3 \mathrm{mX} 3 \mathrm{~m})$, having $60 \mathrm{~cm}$ distance between rows and $20 \mathrm{~cm}$ between plants. The net harvestable area was $5.4 \mathrm{~m}^{2}(1.8 \mathrm{mx} 3 \mathrm{~m})$ leaving one outer most row as border.

DAP (100 kg/ha ), as a source of Phosphorous was applied at planting, application of gypsum $672 \mathrm{~kg} / \mathrm{ha}$ was performed at early flowering stage; while Tied ridge and application of supplementary irrigation were done at the end of rainy season. The tied ridge had $20 \mathrm{X} 30 \mathrm{~cm}$ depth of the soil. (Table 1)

\section{Crop water requirement and irrigation scheduling}

Meteorological data (maximum and minimum temperature, relative humidity, sunshine hours, rainfall and wind speed) were collected from National Meteorology Agency Mekelle branch. Crop water requirement was determined using modified FAO Penman Menteith method [6]. Reference evapotanspiration $\left(\mathrm{ET}_{0}\right.$ ) was calculated based on the climatic data using CWAT software. While the other parameters were calculated as:

Crop water requirement $(\mathrm{Etc})=\mathrm{Eto}{ }^{\star} \mathrm{Kc}(\mathrm{crop}$ coefficient at each growth stage of the crop)

Gross irrigation $(\mathrm{GI})=\mathrm{Net}$ irrigation $(\mathrm{NI}) /$ application efficiency (Ea), Ea was taken as $85 \%$

$\mathrm{NI}=\mathrm{Etc}-\mathrm{Pe}(\mathrm{Pe}=$ effective rain fall $)$, since there was no rain fall during supplementary irrigation time NI=Etc. Irrigation was started at late September for both locations. Accordingly, irrigation water was applied for the specific treatments/plots every five days as supplementary.

\section{Soil sample collection and analysis}

At planting, soil samples were randomly collected from each field to a depth of 0-40 cm with auger. Composite soil samples were prepared from the collected samples. The samples were oven dried at $105^{\circ} \mathrm{C}$ for 24 hours and ground to pass through a $2 \mathrm{~mm}$ sieve for physical and chemical analysis. Soil samples were analyzed for relevant soil parameters of bulk density, $\mathrm{Ca}, \mathrm{Mg}$ and texture, permanent wilting point, and field capacity. Samples were also collected from each plot at harvest and the moisture content was determined by oven drying at $105^{\circ} \mathrm{C}$ till constant weight.

\section{Isolation and identification of aspergillus in laboratory}

Groundnut kernel seed was examined in laboratory and the incidence and severity of Aspergillus infection was recorded based on incidence and severity percentage as described by [7]. Hundred kernels of groundnut samples from bulk were taken randomly from each experimental plot for lab analysis. Using the blotter plate method

\begin{tabular}{|c|c|c|c|}
\hline Code Number & $\begin{array}{c}\text { Treatments } \\
\text { combination }\end{array}$ & $\begin{array}{c}\text { Code } \\
\text { Number }\end{array}$ & $\begin{array}{c}\text { Treatments } \\
\text { combination }\end{array}$ \\
\hline 1 & C & 9 & SI+TD \\
\hline 2 & GP & 10 & SI+F \\
\hline 3 & SI & 11 & TD+F \\
\hline 4 & TD & 12 & GP+SI+TD \\
\hline 5 & F & 13 & GP+SI+F \\
\hline 6 & GP+SI & 14 & GP+TD+F \\
\hline 7 & GP+TD & 15 & SI+TD+F \\
\hline 8 & GP+F & 16 & SI+TD+F+GP \\
\hline
\end{tabular}

$\mathrm{C}=$ Control, $\mathrm{GP}=$ gypsum, $\mathrm{SI}=$ supplementary irrigation, $\mathrm{TD}=$ tied ridge, $\mathrm{F}=$ fertilizer (DAP)

Table 1: list of treatments and treatments combinations. 


\begin{tabular}{|c|c|c|}
\hline \multirow{2}{*}{ Soil characteristics } & \multicolumn{2}{|c|}{ Location } \\
\cline { 2 - 3 } & Hadinet & Lemelem \\
\hline $\mathrm{pH}_{(1: 2.5)}$ & 7.04 & 7.06 \\
\hline $\mathrm{EC}_{(1.2 .5)}$ & 0.04 & 0.05 \\
\hline $\mathrm{OC}(\%)$ & 0.26 & 0.14 \\
\hline Olsen-P $(\mathrm{mg} / \mathrm{kg})$ & 6.41 & 3.51 \\
\hline Total- $\mathrm{N}(\%)$ & 0.08 & 0.05 \\
\hline Exch $\mathrm{Na}(\mathrm{mg} / \mathrm{kg})$ & 31.33 & 14.33 \\
\hline Exch $\mathrm{K}(\mathrm{mg} / \mathrm{kg})$ & 21.33 & 10.67 \\
\hline Exch Ca+mg (mlieq/lit) & 6.47 & 6.73 \\
\hline Exch Ca (mlieq/lit) & 1.53 & 1.4 \\
\hline Sand $(\%)$ & 94 & 94 \\
\hline Silt $(\%)$ & 1 & 1 \\
\hline Clay (\%) & 5 & 5 \\
\hline texture & sand & sand \\
\hline
\end{tabular}

Table 2: Soil characteristics of experimental site.

\begin{tabular}{|l|c|l|c|c|c|c|c|c|}
\hline Location & $\begin{array}{c}\text { Root } \\
\text { depth } \\
\text { (cm) }\end{array}$ & Texture & $\begin{array}{c}\text { Bulk } \\
\text { density }\end{array}$ & FC & PWP & $\begin{array}{c}\text { TAW (\%) } \\
\text { FC-PWP }\end{array}$ & $\begin{array}{c}\text { TAW } \\
\text { (volume) } \\
\text { cm }\end{array}$ & $\begin{array}{c}\text { TAW } \\
\text { mm/m }\end{array}$ \\
\hline Hadinet & $0-40$ & sand & 1.12 & 6.10 & 1.25 & 4.90 & 5.51 & 55.1 \\
\hline & $41-80$ & sand & 1.22 & 9.60 & 4.28 & 5.35 & 6.53 & 65.31 \\
\hline Lemelem & $0-40$ & sand & 1.11 & 6.12 & 1.25 & 4.87 & 5.12 & 54.22 \\
\hline & $41-80$ & sand & 1.23 & 9.64 & 4.28 & 5.36 & 6.57 & 65.75 \\
\hline
\end{tabular}

ITAW=total available water

Table 3: Field capacity (FC), permanent wilting point (PWP), and bulk density of experimental site.

[8] the seeds were soaked in distilled water for three minutes and surface sterilized by soaking in $1 \%$ sodium hypochlorite solution for one minute and rinsed three times with distilled water so as to protect from other external contamination. Then, the kernels were subjected to examination by placing them on moistened germination paper in the sterile plastic tray at an equal distance sealed with paraflin and were grown. The seeds were incubated for 5 days at $28^{\circ} \mathrm{C}$ with 12 hour day light and 12 hour dark. Then kernels infected by Aspergillus spp ( A.fluvs and A.nigr )were counted based on the color of the fungus as described by [9].

Incidence and severity of each fungus types were determined according to [7]. Incidence as the percentage of number of Aspergillus infected samples by the fungus to the whole sample size as:

$\mathrm{I}=\mathrm{n} / \mathrm{N}^{\star} 100, \mathrm{n}$ represents number of Aspergillus infected sample and $\mathrm{N}$ represent the total sample size

The severity (\%) of each fungus was expressed as a percentage of infected grains per 100 plated seeds as:

\section{$\mathrm{S}(\%)=\mathrm{n} / \mathrm{N}^{\star} 100$,} seeds

Where $\mathrm{n}$ is the number of infected seeds and $\mathrm{N}$ is the total planted

\section{Statistical analysis}

Analysis of variance (ANOVA) was carried out using Genstat software $13^{\text {th }}$ version. Treatment means showing significant differences at 5\% level of significance were compared using Duncan's Multiple Range Test (DMRT). As the value consisted of small whole numbers and range between 0 and 30\% square root transformation method was employed before statistical analysis. Percentage data on fungal infection were transformed using square root method as described by [10-12].

\section{Result and Discussion}

\section{Soil Characteristics}

Results of soil analysis for soil sample taken before planting indicated that the proportion of sand, silt and clay was $94 \%, 1 \%$ and $5 \%$, respectively. As a result the textural classes of the experimental soils are classed as sandy. The $\mathrm{pH}$, values of soil in Hadinet and Lemlem was 7.04 and 7.06 (Table 2) respectively which indicated that the experimental soils are almost neutral and within the ideal $\mathrm{pH}$ range value for groundnut production. In addition the EC of Hadinet and Lemlem were 0.04 and $0.05 \mathrm{mmhos} / \mathrm{cm}$ (Table 2), respectively indicating that the sites were non saline.

Total available water for the experimental areas was $55.1 \mathrm{~mm}$ and $54.22 \mathrm{~mm}$ at $0-40 \mathrm{~cm}$ root depth at Hadinet and Lemlem, respectively (Table 3).While the total available water at a depth of $41-80 \mathrm{~cm}$ was 65.31 and $65.75 \mathrm{~mm} / \mathrm{m}$ at Hadinet and Lemlem experimental sites, respectively (Table 3 ).This result also agrees with the results of [6] where it is described that the values of total available soil water of sandy soil ranges between $50 \mathrm{~mm}-110 \mathrm{~mm} / \mathrm{m}$ (Table 3 ).

\section{Soil water content at harvest}

Soil moisture content was measured at harvest. Comparison among different management options in retaining water and their effect on improving yield of groundnut as well as impact in minimizing Aspergillus infection were determined. Analysis of variance on soil moisture determination at harvesting in Hadinet indicated that no significant difference $(\mathrm{P}<5 \%)$ was observed among the different management options at a soil depth of $(0-40 \mathrm{~cm})$. But significant difference (at $\mathrm{P}<5 \%$ ) was observed at soil depth of $41-80 \mathrm{~cm}$ (Table

\begin{tabular}{|c|c|c|c|c|}
\hline \multirow{4}{*}{$\begin{array}{l}\text { Treatments } \\
\text { Mgt options) }\end{array}$} & \multicolumn{4}{|c|}{ Moisture content (\%) } \\
\hline & \multirow{2}{*}{\multicolumn{2}{|c|}{$\begin{array}{c}\text { Hadinet } \\
\text { Soil depth }(\mathrm{cm})\end{array}$}} & \multirow{2}{*}{\multicolumn{2}{|c|}{$\begin{array}{c}\text { Lemlem } \\
\text { Soil depth }(\mathrm{cm})\end{array}$}} \\
\hline & & & & \\
\hline & $0-40$ & $41-80$ & $0-40$ & $41-80$ \\
\hline C & 1.87 & $3.06 a$ & $3.93 a$ & $4.32 a$ \\
\hline $\mathrm{F}$ & 3.57 & $5.63 a b$ & $7.30 b$ & $8.85 b c$ \\
\hline GP & 4.16 & $6.05 b$ & $7.37 \mathrm{~b}$ & $8.35 a b$ \\
\hline $\mathrm{GP}+\mathrm{F}$ & 3.12 & $8.86 \mathrm{~cd}$ & $10.09 \mathrm{cde}$ & $9.73 b c$ \\
\hline GP+SI+TD & 5.15 & $9.04 d$ & $12.61 \mathrm{ef}$ & 14.23de \\
\hline $\mathrm{GP}+\mathrm{SI}$ & 5.07 & $7.35 \mathrm{bcd}$ & $8.50 \mathrm{bc}$ & $9.86 \mathrm{bc}$ \\
\hline $\mathrm{GP}+\mathrm{SI}+\mathrm{F}$ & 4.23 & $6.43 \mathrm{bcd}$ & $9.62 \mathrm{bcd}$ & $9.74 b c$ \\
\hline $\mathrm{GP}+\mathrm{TD}$ & 3.22 & $6.13 b$ & $8.02 b c$ & $8.94 b c$ \\
\hline $\mathrm{GP}+\mathrm{TD}+\mathrm{F}$ & 3.78 & $6.19 b$ & $9.20 \mathrm{bc}$ & $10.16 \mathrm{bcd}$ \\
\hline SI & 5.51 & $7.55 \mathrm{bcd}$ & 11.93def & $12.22 \mathrm{bcde}$ \\
\hline $\mathrm{SI}+\mathrm{F}$ & 4.32 & $7.70 \mathrm{bcd}$ & $10.15 \mathrm{cde}$ & $11.58 \mathrm{bcde}$ \\
\hline SI+TD & 6.46 & $6.66 \mathrm{bcd}$ & $13.68 f$ & $14.31 \mathrm{de}$ \\
\hline $\mathrm{SI}+\mathrm{TD}+\mathrm{F}$ & 5.60 & $8.92 d$ & $11.96 \mathrm{def}$ & 13.10cde \\
\hline $\mathrm{SI}+\mathrm{TD}+\mathrm{F}+\mathrm{GP}$ & 4.34 & $7.31 \mathrm{bcd}$ & $12.91 f$ & $14.63 e$ \\
\hline TD & 4.03 & $6.90 \mathrm{bcd}$ & $7.04 b$ & 8.30ab \\
\hline $\mathrm{TD}+\mathrm{F}$ & 3.39 & $5.29 a b$ & $9.07 b c$ & $10.87 \mathrm{bcde}$ \\
\hline DMRTa 0.5 & ns & 2.718 & 2.690 & 4.267 \\
\hline CV \% & 35.9 & 23.9 & 16.8 & 24.2 \\
\hline
\end{tabular}

aAny means having the common letter are not significantly different at the $5 \%$ level of significance

Table 4: Effect of Agronomic management options on moisture retention in different soil depth at harvesting. 


\begin{tabular}{|c|c|c|c|c|c|}
\hline \multirow[b]{3}{*}{ No. } & \multirow[b]{3}{*}{ Trt } & \multicolumn{4}{|c|}{ Incidence (yes/no), $1=$ yes, $0=$ no } \\
\hline & & \multicolumn{2}{|c|}{ A.flavus } & \multicolumn{2}{|c|}{ A.niger } \\
\hline & & Hadinet & Lemelm & Hadinet & Lemelm \\
\hline 1 & C & 1 & 1 & 1 & 1 \\
\hline 2 & GP & 1 & 1 & 1 & 1 \\
\hline 3 & SI & 0 & 1 & 1 & 1 \\
\hline 4 & TD & 1 & 1 & 1 & 1 \\
\hline 5 & $\mathrm{~F}$ & 1 & 1 & 1 & 1 \\
\hline 6 & $\mathrm{GP}+\mathrm{SI}$ & 1 & 1 & 1 & 1 \\
\hline 7 & $G P+T D$ & 1 & 1 & 1 & 1 \\
\hline 8 & $\mathrm{GP}+\mathrm{F}$ & 1 & 1 & 1 & 1 \\
\hline 9 & SI+TD & 1 & 1 & 1 & 1 \\
\hline 10 & $\mathrm{SI}+\mathrm{F}$ & 1 & 1 & 1 & 1 \\
\hline 11 & $T D+F$ & 1 & 1 & 1 & 1 \\
\hline 12 & $\mathrm{GP}+\mathrm{SI}+\mathrm{TD}$ & 1 & 1 & 1 & 1 \\
\hline 13 & $\mathrm{GP}+\mathrm{SI}+\mathrm{F}$ & 1 & 1 & 1 & 1 \\
\hline 14 & $G P+T D+F$ & 1 & 1 & 1 & 1 \\
\hline 15 & $\mathrm{SI}+\mathrm{TD}+\mathrm{F}$ & 1 & 1 & 1 & 1 \\
\hline 16 & $\mathrm{SI}+\mathrm{TD}+\mathrm{F}+\mathrm{GP}$ & 1 & 1 & 1 & 0 \\
\hline \multicolumn{2}{|r|}{$\mathrm{n} / \mathrm{N}^{*} 100$} & $15 / 16^{*} 100$ & $16 / 16^{*} 100$ & $16 / 16 * 100$ & $15 / 16 * 100$ \\
\hline \multicolumn{2}{|r|}{$(\%)$} & $93 \%$ & $100 \%$ & $100 \%$ & $93 \%$ \\
\hline
\end{tabular}

Table 5: Incidence of A.flavus and A.niger.

\begin{tabular}{|c|c|c|c|c|}
\hline \multirow[t]{2}{*}{ Treatments } & \multicolumn{2}{|c|}{ Hadinet } & \multicolumn{2}{|c|}{ Lemlem } \\
\hline & $\begin{array}{c}\text { A.flavus } \\
\text { Infection (\%) }\end{array}$ & $\begin{array}{c}\text { A.niger } \\
\text { Infection (\%) }\end{array}$ & $\begin{array}{c}\text { A.flavus } \\
\text { Infection (\%) }\end{array}$ & $\begin{array}{c}\text { A.niger } \\
\text { Infection (\%) }\end{array}$ \\
\hline C & $17.3 d$ & 5.7 & $19.3 f$ & 6.3 \\
\hline $\mathrm{F}$ & $9.7 \mathrm{bcd}$ & 6.3 & $7.7 e$ & 5.0 \\
\hline GP & 7.0abc & 5.0 & $8.0 \mathrm{e}$ & 4 \\
\hline $\mathrm{GP}+\mathrm{F}$ & $10.0 \mathrm{~cd}$ & 5.3 & 7.3de & 2.0 \\
\hline $\mathrm{GP}+\mathrm{SI}+\mathrm{TD}$ & 4.3abc & 3.0 & $4.7 a b$ & 4.0 \\
\hline $\mathrm{GP}+\mathrm{SI}$ & $6.7 a b c$ & 3.3 & $5.7 a b c$ & 2.3 \\
\hline $\mathrm{GP}+\mathrm{SI}+\mathrm{F}$ & $10.3 \mathrm{~cd}$ & 4.0 & $5.0 \mathrm{ab}$ & 1.7 \\
\hline$G P+T D$ & $5.7 a b c$ & 3.7 & 7.3de & 2.3 \\
\hline $\mathrm{GP}+\mathrm{TD}+\mathrm{F}$ & $10.0 \mathrm{bcd}$ & 3.3 & $8.0 \mathrm{e}$ & 3.7 \\
\hline SI & $4.0 \mathrm{ab}$ & 2.7 & $6.0 \mathrm{bcd}$ & 2.3 \\
\hline $\mathrm{SI}+\mathrm{F}$ & $5.0 a b c$ & 2.3 & $6.7 \mathrm{cde}$ & 2.7 \\
\hline SI+TD & $3.0 a$ & 1.3 & $4.3 a$ & 2.7 \\
\hline $\mathrm{SI}+\mathrm{TD}+\mathrm{F}$ & 6. $0 a b c$ & 3.7 & $5.0 \mathrm{ab}$ & 1.7 \\
\hline $\mathrm{SI}+\mathrm{TD}+\mathrm{F}+\mathrm{GP}$ & $10.3 \mathrm{~cd}$ & 6.3 & $5.3 a b c$ & 2.3 \\
\hline TD & 7.7abc & 2.7 & $7.7 e$ & 4.0 \\
\hline $\mathrm{TD}+\mathrm{F}$ & 7.3abc & 6.0 & $5.0 \mathrm{ab}$ & 2.7 \\
\hline DMRTa 0.05 & 1.238 & ns & 0.2918 & ns \\
\hline CV \% & 27.5 & 33.5 & 6.5 & 32.5 \\
\hline
\end{tabular}

Table 6: Effect of integrated Agronomic management practices on A.flavus, and A.nige infection (severity) of groundnut seed at Hadinet and Lemlem experimental site means having the common letter are not significantly different at the $5 \%$ level of significance.

4).The integrated management options showed an effect on moisture content percentage at both soil depth in Lemlem experimental site. The highest moisture content $(9.04 \%)$ was recorded in Hadinet in $(41-80 \mathrm{~cm})$ soil depth, where gypsum+supplementary irrigation+tied ridging management options were practiced while the lowest moisture content was observed at the control (Table 4). In Lemlem experimental site the highest (13.68\%) and the lowest (3.93\%) moisture content were recorded in supplementary irrigation+tied ridging management options and control at soil depth of $0-40 \mathrm{~cm}$, respectively this could be due to the better rain fall in amount and distribution than Hadinet. While in a soil depth of $41-80 \mathrm{~cm} 14.63$ percent moisture content was recorded in gypsum+supplementary irrigation+tied ridging and fertilizer combination management options were applied (Table 4).

\section{Identification and incidence of Aspergillus species}

Seeds collected from the experimental areas produced through application of integrated management options were examined for identification and incidence of fungus. Aspergilli were isolated from groundnut seed samples from both experimental sites. These include $A$. flavus and A. niger in both experimental sites. The incidence of $A$. flavus was $93 \%$ and $100 \%$ at Hadinet and Lemlem, respectively (Table 5). The incidence of $A$. niger was $100 \%$ and $93 \%$ at Hadinet and Lemlem, respectively (Table 5). Aspergillus flavus, however was, the dominant fungi (Table 5). This result was also in agreement with the findings of $[11,12]$ which showed that $A$. flavus was the main species occurring in peanut seed.

\section{Effect of integrated agronomic management practices on infection of groundnut seed by aspergillus species}

Groundnut seed infection by Aspergillus species can occur through various conditions. Aspergillus infection can occur under pre and postharvest handling and storage conditions [13]. Study indicated that management practices minimize aflatoxin contamination caused by Aspergillus species. Breeding of resistant varieties, good agricultural production, processing, and handling and storage practices are some of the different management options. But it has been reported by [14] that little success was achieved in the development of groundnut varieties with resistance to aflatoxin contamination. In line with this an experiment was conducted using different management options. Results of the different integrated agronomic management options in minimization of Asperggillus species infection on groundnut are presented below (Table 6).

\section{Effect of soil fertility amendment practices on asspergillus species infection}

Application of fertilizer (DAP) at planting as a means of reducing A.flavus and A.niger infection of groundnut showed a significant effect $(\mathrm{P}<5 \%)$ over the control at Lemlem (Table 6). Significance difference on application of gypsum as a source of calcium over control was observed at both experimental site. From this result it can be suggested that the role of Calcium in reducing aspergillus infection is highly emphasized. Application of calcium in groundnut production alleviates problems like aborted and shriveled kernel seed of peanut and high percentage of 'pops' which are major sources for aspergillus infection. [15] reported that application of gypsum as a source of calcium is crucial to have good quality with totally sound matured groundnut seed.

\section{Effect of moisture retention practices and asspergillus species infection}

Analysis of variance indicated that the integrated management options of soil moisture conservation practices applied at the early flowering stage resulted in a significant effect $(\mathrm{P}<5 \%)$ in Aspergillus flavus infection at both experimental areas. However, the integrated management options did not affect the level of infection in $A$. niger at both locations. The lowest infection levels (3.0 and $4.3 \%$ ) were recorded in SI+TD at Hadinet and Lemlem, respectively. But the highest severity levels (17.3 and 19.3\%) were recorded in control at Hadinet and Lemem experimental site, respectively (Table 6). 


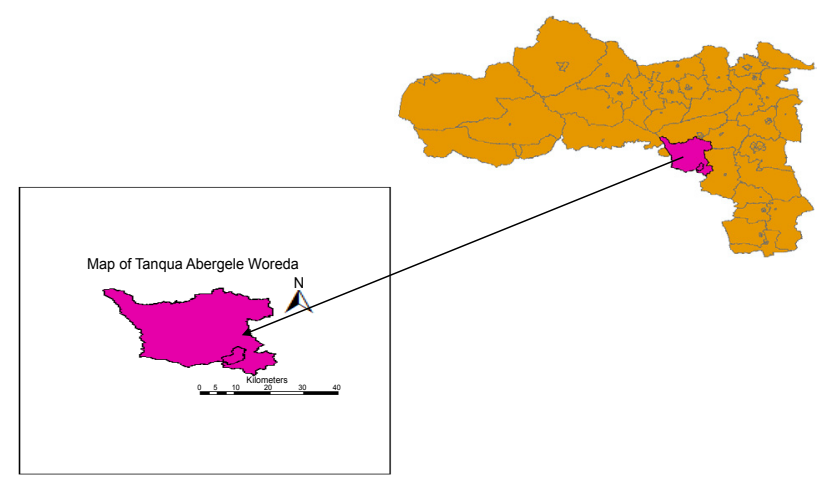

Figure 3: Map of Tanqua Abergela Woreda.

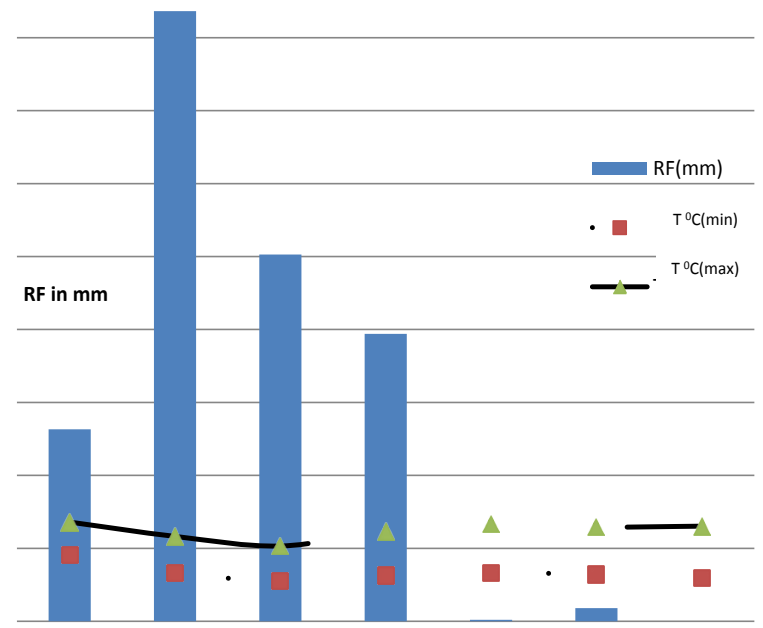

Figure 4: Mean monthly rain fall $(\mathrm{mm})$ and maximum and minimum temperature of Abergelle Wereda during the 2011 growing season Mean monthly rain fall $(\mathrm{mm})$ and maximum and minimum temperature of Abergelle Wereda during the 2011 growing season.

This result also agreed with findings of [16] who found that there was higher infection of peanut by Aspergillus and subsequent higher contamination where there was moisture stress during the last 2040 days to growth period of the crop. In similar manner the role of irrigation on minimizing Aspergillus infection were highly emphasized. Finding on irrigation frequency and sowing date on groundnut reveals that infection of Aspergillus increased as the frequency declined from 7 day to non ( rain fed) [17]. As indicated in (Table 6) no significance difference in A.flavus infection was observed between the two soil moisture amendments options (tied and supplementary irrigation) managements options implemented. In addition combination of all the soil moisture retention amendment practices (TD and SI) had no any significant difference as compared with the double and triple combination of soil fertility amendment practices (Table 6).Un like Lemlem application of fertilizer, gypsum+fertilizer, gypsum+sup plementary+fertilizer, gypsum+tied+fertilizer and supplementary irrigation+fertilizer , gypsum+tied ridge combinations did not showed a significant over the control (Table 6). This might occur due to termite a problem which is serious problem in the areas well as other factors which result in moisture difference in the experimental plots.

\section{Moisture content at harvesting and aspergillus infection of groundnut}

Statistical analysis indicated that moisture content and Aspergillus infection have inverse relations (Figure 3 and 4). Moisture content increased from $3 \%$ at control to $9.04 \%$ in supplementary irrigation+tied ridge+gypsum combinations at Hadinet (Figure 3). The infestation level of Aspergillus decreased from $17 \%$ at control to $3 \%$ in supplementary irrigation and tied ridge combination at Hadinet (Figure 3). In Lemlem the moisture content ranged from $4.32 \%$ in control to $14.63 \%$ in supplementary irrigation, tied ridge, Fertilizer (DAP) and gypsum combinations. As a result the infection level of Aspergillus decreased from $19.3 \%$ in control (without intervention of any agronomic practices) to $4.3 \%$ in supplementary irrigation and tied ridge combination (Figure $4)$.

\section{Conclusion}

Application of gypsum as a source of calcium at early flowering stage significantly lowered Aspergillus infection compared over the control at Hadinet and Lemlem experimental sites.

Application of DAP fertilizer significantly lowered Aspergillus infection only at Lemlem experimental site indicating that moisture has a direct relationship with Aspergillus infection.

Application of soil moisture conservation practice (tied ridging) at early flowering stage of groundnut and supplementary irrigation at the cessation of rain fall significantly lowered Aspergillus infection compared to control at Hadinet and lemlem experimental site. At Hadinet experimental site no significant effect was observed between tied ridge and supplementary irrigation application as means of reducing aspergillus infection. This indicated that based on the availability of these practices, they can serve as a means of reducing aspergillus infection.

Though there was no consistency in reducing the infestation level of Aspergillus flavus over all agronomic combination practices, combination of supplementary irrigation, tied ridge, fertilizer and gypsum reduced the level of Aspergillus flavus infestation by $68 \%$ over the control.

Supplementary irrigation and tied ridge combination was effective and consistent (as compared to the other agronomic practices) agronomic practices that have significantly reduced level of Aspergillus infection over the control. Seeds samples were infested by Aspergillus flavus and Aspergillus niger. Aspergillus flavus was the dominantly occurred fungus in both locations.

\section{Recommendation}

Soil moisture and fertility amendment practices reduce the level Aspergillus flavus infection level but to what level of aflatoxin these agronomic practices did reduce has to be considered for future research direction in verifying the present investigation across years and locations.

The experiment showed that in areas where water for supplementary irrigation is not available application of tied ridge become as an alternative option in reducing Aspergillus flavus infection.

\section{References}

1. UNIDO (2010) Capacity Building For Aflatoxin Management In Groundnuts In Malawi. Ministry Of Industry and Trade, and Ministry Of Agriculture and Food Security: Government Coordinating Agency. 
Citation: Gebreselassie R, Dereje A, Solomon H (2014) On Farm Pre Harvest Agronomic Management Practices of Aspergillus Infection on Groundnut in Abergelle, Tigray. J Plant Pathol Microb 5: 228. doi:10.4172/2157-7471.1000228

2. Erick L (2009) Minimizing Alfatoxine in Corn. Mississippi state university Extension service.

3. Steven J, Luz BDR (2008) Agriculture and Rural Development. Barrier, Catalyst, or Distraction Standards, Competitiveness, and Africa's Groundnut.

4. Dorner JW (2008) Management and prevention of mycotoxins in peanuts. Food Addit Contam Part A Chem Anal Control Expo Risk Assess 25: 203-208.

5. Legesse $Y$ (1999) Agroecology of zone of Tigray land use planning division of Tigray Buaraue of Agriculture and natural resource.

6. Allen RG, Pereira LS, Raes D, Smith M (1998) Crop evapotranspiration: guideline for computing crop water requirement. Irrigation and drainage paper number 56.FAO, Rome.

7. González HH1, Resnik SL, Boca RT, Marasas WF (1995) Mycoflora of Argentinian corn harvested in the main production area in 1990. Mycopathologia 130: 29-36.

8. ICRISAT (2005) Aspergillus flavus seed infection and aflatoxin estimation by ELISA and Aflatoxin management in groundnut.

9. Pitt JI, Hocking AD, Glenn DR (1983) An improved medium for the detection of Aspergillus flavus and A. parasiticus. J Appl Bacteriol 54: 109-114.

10. Gomez AK, Gomez AA (1984): Statistical Procedures for Agricultural Research Second edition. John Wiley and Sons Inter-Science Publications. New York.
11. Idress HA, Laith TAA, Muftah AN, Ibrahim AAB, Maziah Z, et al. (2010) Screening of fungi associated with commercial grains and animal feeds. World Applied Science Journal, 9: 746- 756.

12. Sultan $Y 1$, Magan N (2010) Mycotoxigenic fungi in peanuts from different geographic regions of Egypt. Mycotoxin Res 26: 133-140.

13. Mehan VK, Mayee CD, Jayanthi S, McDonald D (1991) Pre-harvest seed infection by Aspergillus flavus group of fungi and subsequent aflatoxin contamination in groundnuts in relation to soil types. Plant Soil 136: 239-248.

14. Waliyar F, Ba A, Hamma H, Bonkoungou S, Bosc JP (1994) Sources of resistance to Aspergillus flavus and aflatoxin contamination in groundnut genotypes in West Africa. Plant Disease, 78: 704-708.

15. Florence RJ (2011) Fertilization of Peanut (Arachis hypogaea L.) with Calcium: Influence of Source, Rate, and Leaching on Yield and Seed Quality. Msc. thesis, Auburn University, Auburn, Alabama.

16. Cole RJ, Sanders TJ, Dorner JW, Blankenship PD (1989) Environmenta conditions required to induce pre-harvest concentration in groundnut Summary of six years research.

17. Craufurd PW, Prasad PVV, Waliyar F, Taheri A (2006) Drought, pod yield, preharvest Aspergillus infection and aflatoxin contamination on peanut in Niger Field Crops Research 98: 20-29. 